leads to the speculation that patterning might have developed in SAPR-D $S$ s if more acquisition trials had been run, since faster running on nonrewarded trials in the single-alternation paradigm is usually observed prior to the development of patterning appropriate to the reward contingency. This suggests that the postdelay interval might not completely mask the reinforcement aftereffects.

The fact that Group SAPR-D showed a tendency to be less resistant to extinction than the controls is somewhat confusing, since both the sequential aftereffects hypothesis and the majority of the postreward delay studies would suggest that these animals should be more resistant to extinction. Perhaps extinction behavior is affected more by the longer overall nonrewarded goalbox confinement time of the Ss during extinction than by the postreward delay per se.

\section{REFERENCES}

AMSEL,A. The role of frustrative non-reward in noncontinuous reward situations. Psychological Bulletin, 1958, 55, 102-119.

BLOOM, J. M. \& CAPALDI, E. J. The behavior of rats in relations to complex patterns of partial reinforcement. Journal of Comparative \& Physiological Psychology, 1961, 54, 261-265.

BOWEN, J. Effect of post-reward confinement on choice behavior. Psychonomic Science, $1966,6,131$.

CAPALDI, E. J. Partial reinforcement: A hypothesis of sequential effects. Psychological Review, 1966, 73, 459-477.

CAPALDI, E. J. A sequential hypothesis of instrumental learning. In K. W. Spence and J. T. Spence (Eds.), The psychology of learning and motivation. New York: Academic Press, 1967. Pp. 67-156.

CAPALDI, F. 1., \& SPIVEY, J. E. Effect of goalbox similarity on the aftereffect of non-reinforcement and resistance to extinction. Journal of Experimental Psychology, 1963, 66, 461-465.

CAPALDI, E. J., \& STANLEY, L. R. Temporal propertics of reinforcement aftereffects. Journal of Experimental Psychology, 1963, $65,169-175$

CAPALDI, E. J., VEATCH, R. L., \& STEFANIAK, D. E. Stimulus control of patterning behavior. Journal of Comparative \& Physiological Psychology, 1966, 61, 161-164.

COGAN, D. C. Post-reinforcement delay in extinction: A failure to replicate. Psychonomic Science, 1966, 6, 343-344.

FEHRER, E. Effects of reinforcement and of pre- and post-rcinforcement delays on learning and extinction. Journal of Experimental Psychology, 1956, 52, 167-176.

MoCAIN, G., \& BOWEN, J. Pre- and post-reinforcement delay with a small number of acquisition trials. Psychonomic Science. $1967,7,121-122$

TYLER, D. W., WORTZ, E. C., \& BITTERMAN, M. E. The effect of random and alternating partial reinforcement on resistance to extinction in the rat. American Journal of Psychology, 1953, 66, 57-65.

WALL, A. M., \& GOODRICH, R. P. Differential responding on reinforcement and nonreinforcement trials occurring in fixed repeating patterns. Psychonomic Science, $1964,1,193-194$

NOTF

1.D.C. Cogan, Double runway effects of partial reinforement. Unpublished manuscript, 1964.

\title{
Visual factors in observational learning with rats
}

\author{
ROBERT W. POWELL and RICHARD BURNS \\ University of South Florida, Tampa, Fla. 33620
}

Albino rats learned to leverpress for food reinforcement through observation as quickly as hooded rats. Hooded rats, observing a trained rat through a screen, which reduced visibility, learned just as quickly as hooded rats which observed the trained rat through Plexiglas. Leverpressing was more quickly acquired by hooded rats that were shaped than hooded rats learning through observation. The results suggest that the contribution of visual observation to learning in rats is relatively minor and does not involve a high degree of visual acuity.

Several recent experiments have compared observational procedures with shaping as techniques for training rats to leverpress for positive reinforcement (Corson, 1967; Powell, 1968; Powell, Saunders, \& Thompson, 1968; Jacoby \& Dawson, 1969). The results of these experiments do not agree. Powell (1968) and Powell et al (1969) found shaping to be the most effective training method with albino rats. Corson and Jacoby and Dawson found no difference, or that observation was superior, depending upon the measure of performance evaluated. These experiments employed hooded rats as Ss.

There appear to be several possible explanations for these differences. Jacoby and Dawson suggest that the skill of the person who is shaping the animal can have a significant influence on the rate of acquisition. A second possibility is the existence of differences in vision between rats with nonpigmented eyes (albino rats) and pigmented eyes (hooded rats). Experiments have already shown that hooded rats are superior to albino rats in both visual acuity (Lashley, 1930) and depth perception (Greenhut, 1954; Davidson \& Walk, 1969). A third possibility, although it seems unlikely, is that hooded rats acquire a response more

* Reprints may be obtained from Robert W. Powell. Department of Behavioral Science. University of South I'lorida. Tampa. F'la. 33620. slowly through shaping than do albino rats.

The purpose of the present experiment was threefold: (1) to compare observational learning of a leverpress response in albino rats and hooded rats, (2) to compare observational learning and shaping of this response in hooded rats, and (3) to assess the contribution of vision to observational learning with hooded rats. Jacoby \& Dawson (1969) employed techniques designed to optimize the visual process in their experiment. Most of these techniques were incorporated in the present experiment for the same purpose. METHOD

The $\mathrm{Ss}$ were 11 naive albino rats, Sprague-Dawley derived, and 48 naive hooded rats, Long-Evans strain, or Long-Evans derived. All rats were between 120 and 180 days old at the start of the experiment. The animals were food deprived for $23 \mathrm{~h}$ prior to each experimental session and then had free access to food for $1 \mathrm{~h}$ after the session. Water was available at all times in the home cages.

The test apparatus was a Ralph Gerbrands operant-conditioning chamber with a single lever. All of the modifications employed by Jacoby \& Dawson (1969) were incorporated in the present chamber. These included (1) positioning the lever $3 \mathrm{in}$. directly above the dipper opening, (2) placement of a clear Plexiglas partition at a diagonal (corner to corner) within the chamber, (3) covering of the outside 
Table 1

Number of Test Sessions to Criterion

\begin{tabular}{|c|c|c|c|c|c|c|}
\hline Subject & $\begin{array}{l}\text { Albino } \\
\text { Observe }\end{array}$ & $\begin{array}{c}\text { Hooded } \\
\text { Observe }\end{array}$ & $\begin{array}{c}\text { Hooded } \\
\text { Shape }\end{array}$ & $\begin{array}{l}\text { Hooded } \\
\text { Observe } \\
\text { (Screen) }\end{array}$ & $\begin{array}{l}\text { Hooded } \\
\text { Control } 1\end{array}$ & $\begin{array}{l}\text { Hooded } \\
\text { Control? }\end{array}$ \\
\hline 1 & 2 & 11 & 8 & 6 & 17 & 11 \\
\hline 2 & 3 & 13 & 6 & 11 & 9 & 8 \\
\hline 3 & 10 & 12 & 4 & 6 & 6 & 13 \\
\hline 4 & 13 & 12 & 3 & 9 & 9 & 10 \\
\hline 5 & 18 & 19 & 8 & 9 & 7 & 20 \\
\hline 6 & 2 & 8 & 5 & 7 & 13 & 12 \\
\hline 7 & 5 & 8 & & 7 & 8 & 11 \\
\hline 8 & 5 & 15 & & 8 & $20^{*}$ & $20^{*}$ \\
\hline 9 & 19 & 10 & & 8 & $20^{*}$ & $20^{*}$ \\
\hline 10 & 18 & 3 & & 14 & $20^{*}$ & $20^{*}$ \\
\hline 11 & $20^{*}$ & & & & & $20^{*}$ \\
\hline 12 & & & & & & $20^{*}$ \\
\hline Mean & 10.5 & 11.1 & 5.7 & 8.5 & 14.5 & 14.1 \\
\hline $\mathrm{SD}$ & 6.95 & 4.10 & 1.78 & 2.33 & 3.65 & 7.82 \\
\hline
\end{tabular}

*Did not learn.

chamber walls with semiopaque paper, and (4) conducting the study in a room where extraneous auditory stimuli rarely occurred. Borden's sweetened condensed milk diluted by an equal volume of water was the reinforcer. This was presented for 3-sec durations on a CRF schedule for leverpressing.

All sessions were $30 \mathrm{~min}$ per day, consisting of a $15-\mathrm{min}$ training period followed by a 15-min test period. The criterion for learning was 50 or more responses during the test period. If a rat failed to reach this criterion within 20 sessions, training was terminated. The rats were divided into six groups, which were studied according to the following procedures: (1) Albino observe-The 11 albino rats were placed in the side of the test chamber that did not permit access to either the dipper or the lever. They had the opportunity to observe trained albino rats (models) respond for milk reinforcement on a CRF schedule for the $15-\mathrm{min}$ test period. At the end of this time the partition and the model rat were removed. Models were used which were preselected on the basis of reliably making 75 or more responses in $15 \mathrm{~min}$. (2) Hooded observe-Ten hooded rats were studied according to the same procedure except that hooded rats served as models. (3) Hooded shape-Six hooded rats were dipper trained and were then differentially reinforced for successive approximations to the criterion response during the training periods. (4) Hooded observe with screen-Ten hooded rats were studied under the same conditions as (1), except that the partition consisted of two layers of hardware cloth laminated between two pieces of Plexiglas. This reduced the amount of light transmitted through the partition by $52 \%(1.20$ to $.57 \mathrm{fc})$, as measured by a Milli-Candella photometer. (5) Hooded control, 1-Ten hooded rats were studied under the same conditions as those of Group 1 except that the partition was opaque, so that visual observation was impossible. (6) Hooded control, 2-Twelve hooded rats in this group were separated from the manipulandum and dipper by an opaque partition during the training period. No model rat was present during this time; however, the dipper operated automatically every $7.5 \mathrm{sec}$. This procedure allowed for adaptation to auditory stimuli produced by the operation of the dipper. The rationale for these control procedures is based in part on recent studies suggesting that animals receiving food reward emit specific odors that can serve as cues to other animals of the same species (Ludvigson \& Sytsma, 1967; Topping \& Cole, 1969; Davis, 1970).

The number of test sessions to criterion is presented for each rat in Table 1 , with means and standard deviations for each group. Eight of the nine rats that did not of Kruskal-Wallis analyses of variance were performed which compared the hooded observe group with each of the other groups in succession. Only the hooded shape group was significantly different from this group $(p<.02)$. Although the rats that did not learn were given the lowest ranks in the Kruskal-Wallis analysis, this procedure does not seem to give adequate weight to the differences between these animals and those that did learn. For this reason a chi-square test was performed comparing the hooded observe and hooded screen groups with the two control groups. This test revealed that the difference between groups in learners vs nonlearners was significant beyond the .01 level of confidence.

The principal results of the experiment can be summarized as follows: (1) There was no difference between hooded rats and albino rats in observational learning of leverpressing; (2) a group of hooded rats

\section{RESULTS AND DISCUSSION} learn were in the control groups. A series that observed the model through a screen which reduced visibility learned just as well as hooded rats that observed the model through clear Plexiglas; (3) hooded rats acquired leverpressing more quickly through shaping than through observation; and (4) the observational groups differed from the control groups in the number of learners vs nonlearners, but there was no difference between groups in the number of trials to criterion for the animals that did learn.

The present results indicate that the observational learning that occurred did not involve a very high degree of visual acuity. The performance of rats under the control procedures suggests, in addition, that the contribution of visual observation to learning is relatively minor in rats, which is contrary to the hypothesis of Jacoby \& Dawson (1969).

This experiment demonstrates again that shaping can be a more effective technique than observation for training rats to press a lever. However, as Jacoby and Dawson point out, the effectiveness of shaping is a function of the skill of the shaper. The experiments in this laboratory have employed a large number of undergraduates as shapers, none of whom had any training or experience with this procedure prior to the experiment. Their mastery of the technique suggests that skill at shaping is not difficult to acquire.

\section{REFERENCES}

CORSON. J. A. Observational learning of a lever-pressing response. Psychonomic Science, 1967, 7, 197-198.

DAVIDSON, P. W., \& WALK, R. D. Differential visual depth discrimination of hooded as compared to albino rats. Psychonomic Science. 1969, 5, 207-208.

DAVIS, S. F. Conspecific odors as cues for runway behavior in mice. Psychonomic Science, 1970, 19, 169-170.

GREENHUT, A. M. Visual distance discrimination in the rat. Journal of Experimental Psychology, 1954, 47, 148-152.

JACOBY, K. E., \& DAWSON, M. E. Observation and shaping learning: A comparison using Long-Evans rats. Psychonomic Science, 1969. 16. 257-258.

LASHLEY, K. S. The mechanism of vision: III. The comparative visual acuity of pigmented and albino rats. Journal of Genetic Psychology, 1930, 37, 481-484.

LUDVIGSON, H, W., \& SYTSMA. D. The sweet smell of success: Apparent double alternation in the rat. Psychonomic Science, 1967, 9. 283-284.

POWELL, R. W. Observation learning vs shaping: A replication. Psychonomic Science, 1968, 10, 263-264.

POWELL, R. W.. SAUNDERS, D., \& THOMPSON, W. Shaping, autoshaping and observational learning with rats. Psychonomic Science, $1969,13,167-168$.

TOPPING, J. S., \& COLE, J. M. A test of the 0 ur hypothesis using Mongolian gerbils and a random trials procedure. Psychonomic Science, 1969, 17, 183-184. 